\title{
Consumers' Willingness to Pay and Market Shares for Drinking Milk Profiles with the Region of Origin: Case of Iğdır Province
}

\author{
Yavuz Topcu',a,* \\ ${ }^{1}$ Department of Agricultural Economics, Faculty of Agriculture, Atatürk University, 25240 Erzurum, Turkey
} *Corresponding author

\begin{tabular}{|c|c|}
\hline A R T I C LE INFO & A B S T R A C T \\
\hline $\begin{array}{l}\text { Keywords: } \\
\text { Conjoint analysis } \\
\text { Iğdır } \\
\text { Drinking milk } \\
\text { Willingness to pay } \\
\text { Market share }\end{array}$ & $\begin{array}{l}\text { The aim of the study was to design the drinking milk profiles according to the factors and their levels } \\
\text { effecting on the consumers' purchase decisions towards drinking milk with the region of origin at } \\
\text { the retailer level, and then to determine the market shares (MS) and the consumers' willingness to } \\
\text { pay (WTP). Research data were obtained from } 160 \text { households consuming drinking milk in Iğdir } \\
\text { province. Conjoint Analysis were used to design drinking milk profiles with the region of origin, } \\
\text { and to determine their market shares (MS) and consumers' willingness to pay (WTP). The result of } \\
\text { the study highlighted that the marketing shares of the first three drinking milk profiles maximizing } \\
\text { the consumers' total utilities were calculated as } \% 34, \% 12 \text { and \% } 10 \text { (card number } 7,6 \text { and 1), } \\
\text { respectively. On the other hand, the consumers' willingness to pay under the origins and price levels } \\
\text { of drinking milk were analyzed as } \% 26 \text { for Aegean/Marmara Region, } \% 16 \text { for Northeast Anatolia } \\
\text { Region and } \% 12 \text { for Eastern Black Sea Region at the lowest price levels. By having designed } \\
\text { drinking milk profiles maximizing the consumers' total utilities, the marketing share and penetration } \\
\text { rates of the products could increase, and the product profiles responded to the consumers' } \\
\text { willingness to pay could also satisfy considerably on their purchase decisions. }\end{array}$ \\
\hline
\end{tabular}

Türk Tarım - Gıda Bilim ve Teknoloji Dergisi 7(7): 981-988, 2019

\section{Bölge Orijinli İçme Sütü Profilleri İçin Tüketicilerin Ödeme İstekliliği ve Piyasa Payları: Iğdır İli Örneği}

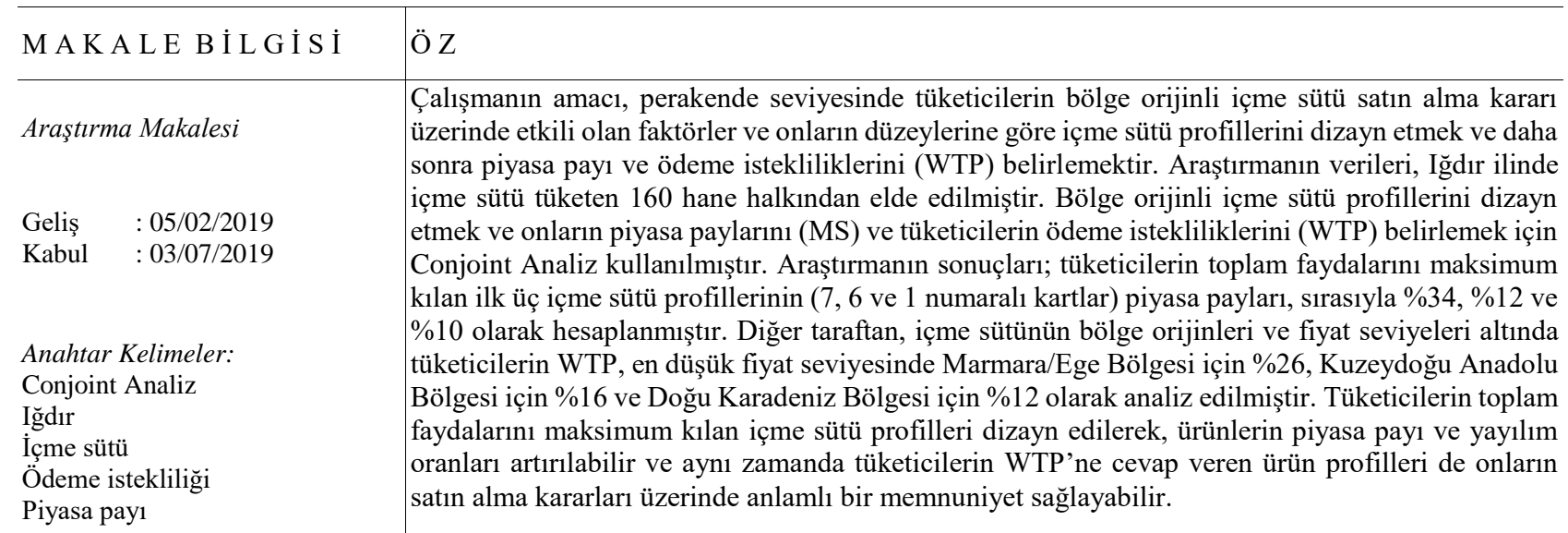




\section{Giriş}

Son y1llarda yaşanan küresel iklim değişiklikleri, tohumların maruz kaldığı genetik modifikasyonlar, üretim ve işleme sürecinde kimyasal ve sentetik katkı maddelerinin kullanılması hem çevre ve doğal kaynaklar hem de beșeri sermaye üzerinde telafisi imkânsız deformasyonlara neden olmaktadır. Diğer taraftan küreselleşme ve bilişim teknolojilerinin etkisi altında piyasa aktörlerinin ekonomik hayata katılım demografisi ve sosyoekonomik değiş̧imler ile pasif yaşam kültürünün benimsenmesi, insanların beslenme ve satın alma alışkanlıkları üzerinde hızlı bir değişime yol açmıştır. Üretim kaynaklarının kalitesini negatif bir șekilde etkileyen bu faktörlerdeki dramatik artı̧̧lar; tüketicilerin daha doğal ve sağlıklı, kimyasallardan ari ve genetik modifikasyonlara maruz bırakılmamış bölge orijini bilinen gıda ürünleri ile yaşanabilir bir çevre arayışlarına yönelmelerine neden olmuştur.

Günümüzde bu felsefeyi benimsemiş tüketicilerin menşe (PDO) ve mahreç (PGI) işaretli gıda ürünleri tüketimi, hem insan sağlığı üzerindeki koruyucu ve pozitif etkisi hem de üretim ve arz zinciri güvenliğinden kaynaklanan piyasa payı artışlarının işletmelere sağladığı katma değerler vasıtasıyla kırsal ve bölgesel kalkınmada da katalizör bir rol oynamaktadır (Groot ve Albusi, 2015; Topcu, 2015; Kan ve ark., 2012). Bütün bu fonksiyonlar, sadece üreten ve arz eden işletmeleri değil aynı zamanda tüketiciler ile toplum çıkarlarını da koruyarak, kırsal ve bölgesel kalkınmaya önemli katkılar sağlamaktadır. Bütün dünyada gida ürünleri tüketiminde aranan duyusal kalite, gıda güvenliği, gen kaynakları ve biyolojik çeşitliliğin korunması, doğal kaynaklar ve çevrenin muhafazası ile bölge orijin tesciline sahip ürünler, piyasalarının genişlemesine ve yeni tasarımlı mamullerin teşekkülüne olanak sağlayarak tüketicilerin daha fazla ödeme istekliliğini (WTP) benimsemelerine neden olmaktadır.

Gıda ürünlerinin tüketiminde aranan bu pozitif nitelikleri teminat altına alan PDO, PGI ve TSG ile tescilli 10.000 coğrafi işaretli gıda ürünlerin dünya piyasasındaki payı 175 milyar Euro'yu aşarken; Fransa, İtalya ve İspanya'nın liderliğinde Avrupa Birliği (AB)'de 1.274 coğrafi işaretli ürünlerin payı 75 milyar Euro ile artış trendini devam ettirmekte ve bu ürünlerin $\% 20$ 'sinin ihracatı ile 15 milyar Euro döviz girdisi sağlanmaktadır (Tekelioğlu, 2016). Fakat Türkiye'de coğrafi işaretli gıda ürünleri için henüz bir iç piyasa potansiyeli oluşturulamadığı ve çalışmaların 2015-2018 Ulusal Coğrafi İşaret Stratejisi ve Eylem Planı kapsamında yürütülerek, kurumsal yap1 ve piyasa potansiyelinin oluşturulması hedeflenmektedir. Bu kurumsal yapıya karşı1lı, 2014-2015 üretim döneminde 13 ülkeye 7 ürün ile 2.500 ton coğrafi işaretli gıda ürün ihracatı gerçekleştirildiği ve bu değerin toplam gıda ihracatının yaklaşık \%10'na tekabül ettiği rapor edilmiştir (Anonim, 2014).

Gerçekten Türkiye'de bu niteliklere haiz olan 209 adet coğrafi işaret almış, fakat 319 adet de işlemi devam eden gıda ürünleri mevcuttur. Hatta ülkemizde 2.500 adet potansiyel ürünün coğrafi işaret ile işaretlenmesinin uygunluğundan da çeşitli raporlarda bahsedilmektedir (TPE, 2018). Bu nitelikleri ile Türkiye, coğrafi işaret tescili alabilecek mamul portföyü yönünden oldukça zengin bir potansiyele sahiptir. Türkiye'de coğrafi işaretlerle tescillenmiş gıda ürünleri arasında tarımsal ürünlerin payı $\% 70$ ve bunlar içerisinde hayvansal ürünlerin pay1 $\% 8$ ile oldukça düşük düzeylerde seyretmektedir (Anonim, 2015). Hâlbuki coğrafi işaretli ürünlerde $\mathrm{AB}$ ülkelerinden Fransa'da bu oran \%30 ve ekonomiye katkısı ise 35 milyar Euro iken; Fransa, İtalya ve İspanya'nın peynirlerinin her birinin ekonomilerine katkıları 1,2-1,6 milyar Euro arasında ve piyasa büyüme oranları da yaklaşık $\% 10$ düzeyinde olmuştur. Ayrıca peynir piyasasının da \% 70 'ine coğrafi işaretli ürünler hâkim konumdadır (Tekelioğlu, 2016).

Çok hızlı büyüyen bir piyasada, riskli ürünler grubunda yer alan süt ve süt ürünlerinin bölge orijini ile tescillenmesi, tüketicilere önemli bir koruma ve gida güvenliği sağlamakta ve bu ürünlere olan talep çok hızlı bir şekilde artmaktadır. Diğer taraftan bölge orijini tescilleri, üreticilerin ürünlerinin koruma altına alınması ile işletmelerin konvansiyonel üretici rakiplerine göre \%50\%250 kadar bir ekonomik avantaj ile sağlanan katma değer (Tekelioğlu, 2016) ve bunun kırsal kalkınma aracı olarak kullanılmasından dolayı dünyadaki piyasa payı hızlı bir şekilde artmaktadır.

Benzer şekilde insanoğlunun yaşamının her evresinde gerekli olan süt ve süt ürünleri, makro ve mikro besin elementleri için iyi bir alternatif olmasının yanında bazı önemli mineraller, protein ve vitaminlerin de temel kaynağı durumundadır. Yüksek değerli proteinleri ve tüm esansiyel aminoasitleri içeriği nedeniyle önemli bir kalsiyum, fosfor, magnezyum ve potasyum kaynağ durumunda olan süt (Şeker ve ark., 2012; Murphy ve ark., 2008; Huth ve ark., 2006), özellikle çocukluk ve yaşlılık dönemleri başta olmak üzere yeterli ve dengeli beslenme için gerekli olan bir gida maddesi ve bileşeni niteliğindedir (Miller, 2000; Black ve ark., 2002; Vaskozen, 2003; Azadbakht ve ark., 2005; Lim ve ark., 2014). İfade edilen faktörlerin etkisi altında fizyolojik ihtiyaçtan sağlanacak temel fayda güdüsü, tüketicilerin süt tüketim motivasyonlarını güçlendirmektedir (Grunert ve Aachmann, 2016; Li ve Drake, 2015; Mobley ve ark., 2014; Allen ve Goddard, 2012).

Oldukça karmaşık satın alma kararını gerekli kılan içme sütünün dünyadaki toplam üretimi 2017 yılında 653 milyon ton düzeyinde olup, süt üretiminde $\mathrm{AB}-28, \mathrm{ABD}$, Hindistan, Brezilya, Çin, Rusya, Yeni Zelanda ve Türkiye lider ülkeler konumundadır (FAOSTAT, 2019). Türkiye yaklaşı 18,8 milyon ton süt üretimiyle dünya sıralamasında 8. sırada yer alırken, toplam üretilen sütün \%91'i sı ğırdan temin edilmektedir (ASUD, 2019; WDS, 2017). Yaklaşı 7,5 milyar nüfusa sahip olan dünyada, kişi başına ortalama süt ve süt ürünleri tüketim miktarı 111,3 $\mathrm{kg}$ olup, gelişmiş ülkelerde $180-575 \mathrm{~kg}$, gelişmekte olan ülkelerde $75-100 \mathrm{~kg}$ ve Türkiye'de ise $236 \mathrm{~kg}$ 'dır. Özelikle Rusya (180 litre), Ukrayna (123 litre), Avustralya (113 litre), Yeni Zellanda (108 litre), ABD (82 litre), Kanada (82 litre), AB-28 (61 litre) kişi başına içme sütü tüketiminde ilk sıralarda yer alırken (WDS, 2017); Türkiye ve araştırma bölgesi olan Iğdır'da ise kişi başına içme sütü tüketimi 18 ve 5 litre düzeyindedir. Türkiye ve Iğdır'da kişi başına süt ve süt ürünleri tüketimi, dünyada lider ülkelerle karşılaştırıldığı zaman; süt ve süt ürünlerinde 1lımlı fakat içme sütü tüketiminde oldukça düşük tüketim trendine (1020 kat daha düşük tüketim) sahiptir. 
Özellikle son yıllarda içme sütü tüketim trendi üzerinde bölge orijini ve geleneksel özellik garantisi, sütün üretim ve işleme teknikleri, aroma, tat ve lezzet gibi duyusal kalite nitelikleri, kimyasal ve sentetik katk1 maddelere maruz kalıp kalmadığı ve hijyen konusundaki gıda güvenliği gibi mamul bilgilerinin belirleyici olduğunu (Uzundumlu ve Topcu, 2016; Denver ve Jensen, 2014; Bonany ve ark., 2013); tüketicilerin bu ürünler için \%25-250 daha yüksek fiyat ödemeye hazır olduklarını ve piyasa paylarının \%1025 daha hızlı bir şekilde arttığını (Grunert ve Aachmann, 2016; Tekelioğlu, 2016; Topcu, 2015; Chamorro ve ark., 2014; Denver ve Jensen, 2014; Munoz ve ark., 2014; Cernea, 2011; Fotopoulos ve Krystallis, 2011; Hassan ve ark., 2011; Vecciho ve Annunziate, 2011; Tsakiridou ve ark., 2009; Aprile ve Gallina, 2008; Murphy ve ark., 2004) rapor eden çok sayıda araştırma mevcuttur.

Tüketim motivasyonu üzerinde etkili olan bu duyusal kalite nitelikleri; araştırma bölgesinin agro-ekolojik yapısı, doğal kaynakların muhafazası, hayvancılığın yüksek rakımlı ve kirletici kimyasallardan uzak mera alanlarında sürdürülmesinden dolayı oldukça yüksek düzeylerde seyretmektedir. Dolayısıyla araştırma bölgesinde bölge orijini ve geleneksel özellik garantisi altında büyük bir nispi avantaja sahip olan çiğ sütün duyusal kalite niteliklerinin pazarlama karması bileşenleri ile bütünleştirilerek gerçek ya da genişletilmiş içme sütü dizaynlarının gerçekleştirilmesi tüketim trendlerinin artışında önemli rol oynayabilir.

Ancak hem ulusal düzeyde hem de araştırma bölgesinde tüketicilerin toplam faydalarını maksimum k1lan bölge orijinli içme sütü profil dizaynları ile bunların piyasa payları ve tüketicilerin ödeme isteklilikleri konularında yapılmış araştırmalara rastlamak mümkün değildir. $\mathrm{Bu}$ yüzden bu çalışma, bölge orijini ve geleneksel özellik garantisi sunan içme sütü tüketiminde etkili olan faktörler ve bunların seviyeleri üzerine odaklı mamul profillerinin belirlenmesi, bunların piyasa payları ve tüketicilerin ödeme istekliliklerinin ortaya konulması ile ekonomi literatürüne önemli bir katkı sağlayabilir. Hedeflenen bu katkılar doğrultusunda çalışmanın amacı, Iğdır ilinde tüketicilerin toplam faydalarını maksimum kılan bölge orijinli içme sütü tüketim tercihi ve satın alma kararı üzerinde etkili olan faktörler ile faktör seviyelerini dikkate alan mamul profillerinin dizayn edilmesi, bunların piyasa paylarının ve tüketicilerin ödeme istekliliklerinin tahmin edilmesidir.

\section{Materyal ve Metot}

Araştırmanın birincil verilerini, Iğdır ilinde ikamet eden ve içme sütü tüketen hane halkları ile yüz yüze yapılan anketlerden elde edilen veriler oluşturmaktadır. İkincil veriler ise, çeşitli kurum ve kuruluşların verileri ile yerli ve yabancı bilimsel çalışma, rapor, dergi ve çeşitli yayınlardan temine dilen araştırma bulgu ve sonuçlarından sağlanmıştır.

\section{Örnek Büyüklüğ̈̈nün Belirlenmesi}

Türkiye'nin Doğu Anadolu Bölgesi'nde yer alan Iğdır ilindeki hane halklarını temsil etme niteliği taşıyan ve örnek kitleye seçilenlerin tek yönlü kümelenmesini önlemek için her bir ilin doğu-batı, kuzey-güney yönlerini kapsayan ana popülasyondaki hane halkları tesadüfi olarak seçilerek, örneklem büyüklüğü belirlenmiştir. Araştırma bölgesinde içme sütü tüketen ve tüketmeyen hane halklarının oranları belirlemek için pilot çalışma yürütülmüş ve tesadüfi olarak seçilen tüketicilerin içme sütü tüketme oranı \%88,2 olarak hesaplanmıştır. Mevcut oran dikkate alınarak, popülasyon büyüklügünün bilinmemesi durumda örnek kitle büyüklüğü aşağıdaki denklem yardımıyla hesaplanmıştır (Topcu, 2015).

$$
\mathrm{n}=\frac{\mathrm{Z}^{2} \times \mathrm{p} \times(1-\mathrm{p})}{\mathrm{c}^{2}}
$$

Burada;

$\mathrm{n} \quad$ : Örnek büyüklüğü

Z : Z değeri, (\%95 güven aralığında 1,96$)$

p : : İçme sütü tüketenlerin oranı $(0,882)$

q : : (1-p) İçme sütü tüketmeyenlerin oranı $(0,118)$

c : Hata terimi, $(0,05= \pm 5)$

Yukarıdaki eşitlikte tüketicilerin içme sütü kullanım oranları dikkate alınarak, araştırma bölgesinde yapılması gereken anket sayısı 160 olarak hesaplanmıştır.

\section{Anket Formlarının Hazırlanması}

Iğdır ilinde içme sütü tüketen hane halklarının satın alma tutum ve davranışları belirleyen içsel ve dışsal ürün nitelikleri ile tüketicilerin sosyoekonomik ve demografik karakteristikleri ile ilgili faktörler, yerli ve yabancı araştırmalarda kullanılan değişkenlerin bölgelere ve ilgili ürüne uyarlanması ile elde edilmiştir. Ön araştırma ile tüketicilerin içme sütü satın alma kararı üzerinde etkili olan içme sütü üretim ve işleme teknikleri, ürün içeriği, bölge orijini, marka ve fiyat gibi perakende seviyesinde dikkate alınan 6 ana faktörler ile onların 17 faktör seviyesi (organik ve geleneksel üretim teknikleri; UHT, pastörize ve ham süt işleme teknikleri; Doğu Karadeniz, Kuzeydoğu Anadolu, Marmara/Ege Bölgesi orijinleri; ulusal, özel ve jenerik marka tipleri; tam, yarım ve sıfır yağlı süt içerikleri; 3 TL/litre baz fiyatı yanında \%100 ve \%200 fiyat artışları ile ödeme istekliliği duyarlıkları için hesaplanan 6 TL/litre ve 9 TL/litre) dikkate alınarak (Çizelge 1), orthogonal dizayn ile 20 içme sütü profil kartları türetilmiştir (Çizelge 2). İçme sütüne ilişkin faktör ve faktör seviyeleri ile 20 ürün profili anket formlarına aktarılarak hedef tüketici kitlelerine sunulmuştur.

Çizelge 1 İçme sütünün nitelik ve nitelik seviyeleri

Table 1 The attributes and their levels of drinking milk

\begin{tabular}{l|lll}
\hline \multicolumn{1}{c|}{ Mamul nitelikleri } & \multicolumn{3}{c}{ Nitelik seviyeleri } \\
\hline Üretim tekniği & \multicolumn{1}{c}{ Organik üretim } & Geleneksel üretim \\
İşleme tekniği & UHT süt & Pastörize süt & Ham (çiğ) süt \\
Marka & Ulusal marka & Özel marka & Jenerik marka \\
Üretim bölgesi (orijin) & Kuzeydoğu Anadolu & Doğu Karadeniz & Marmara/Ege \\
İçeriği (yağ oranı) & Tam yağlı süt & Yarım Yağlı süt & Light süt \\
Fiyat & \multicolumn{1}{c}{ 3 TL } & 6 TL & 9 TL \\
\hline
\end{tabular}


Çizelge 2 Conjoint analiz ile türetilen içme sütü profilleri

Table 2 Drinking milk profiles derived by Conjoint Analysis

\begin{tabular}{|c|c|c|c|c|c|c|}
\hline $\mathrm{PN}$ & Üretim tekniği & İşleme tekniği & Orijini (bölgesi) & Marka & Ürün içeriği & Fiyat \\
\hline 1 & Organik & UHT süt & Doğu Karadeniz & Ulusal marka & Yarım yağlı süt & $6 \mathrm{TL}$ \\
\hline 2 & Organik & Ham süt & Marmara/Ege & Özel marka & Light süt & $6 \mathrm{TL}$ \\
\hline 3 & Geleneksel & UHT süt & Kuzeydoğu Anadolu & Özel marka & Yarım yağlı süt & $9 \mathrm{TL}$ \\
\hline 4 & Organik & Pastörize süt & Kuzeydoğu Anadolu & Jenerik marka & Yarım yağlı süt & $3 \mathrm{TL}$ \\
\hline 5 & Organik & UHT süt & Kuzeydoğu Anadolu & Jenerik marka & Tam yağlı süt & $6 \mathrm{TL}$ \\
\hline 6 & Organik & UHT süt & Marmara/Ege & Ulusal marka & Tam yağl1 süt & $3 \mathrm{TL}$ \\
\hline 7 & Organik & Pastörize süt & Doğu Karadeniz & Özel marka & Tam yağlı süt & $3 \mathrm{TL}$ \\
\hline 8 & Geleneksel & Pastörize süt & Kuzeydoğu Anadolu & Ulusal marka & Light süt & $6 \mathrm{TL}$ \\
\hline 9 & Organik & UHT süt & Marmara/Ege & Jenerik marka & Light süt & $9 \mathrm{TL}$ \\
\hline 10 & Geleneksel & Ham süt & Marmara/ege & Jenerik marka & Yarım yağlı süt & $3 \mathrm{TL}$ \\
\hline 11 & Organik & Pastörize süt & Doğu Karadeniz & Jenerik marka & Light süt & $9 \mathrm{TL}$ \\
\hline 12 & Organik & Pastörize süt & Marmara/Ege & Özel marka & Yarım yağlı süt & $6 \mathrm{TL}$ \\
\hline 13 & Geleneksel & Ham süt & Doğu Karadeniz & Jenerik marka & Tam yağlı süt & $6 \mathrm{TL}$ \\
\hline 14 & Organik & Ham süt & Doğu Karadeniz & Ulusal marka & Yarım yağlı süt & $9 \mathrm{TL}$ \\
\hline 15 & Geleneksel & UHT süt & Doğu Karadeniz & Özel marka & Light süt & $3 \mathrm{TL}$ \\
\hline 16 & Organik & Ham süt & Kuzeydoğu Anadolu & Ulusal marka & Light süt & $3 \mathrm{TL}$ \\
\hline 17 & Geleneksel & Pastörize süt & Marmara/Ege & Ulusal marka & Tam yağlı süt & $9 \mathrm{TL}$ \\
\hline 18 & Organik & Ham süt & Kuzeydoğu Anadolu & Özel marka & Tam yağlı süt & $9 \mathrm{TL}$ \\
\hline $19^{\mathrm{a}}$ & Geleneksel & Ham süt & Kuzeydoğu Anadolu & Özel marka & Tam yağlı süt & $3 \mathrm{TL}$ \\
\hline $20^{\mathrm{a}}$ & Organik & Ham süt & Marmara/Ege & Ulusal marka & Light süt & $3 \mathrm{TL}$ \\
\hline
\end{tabular}

${ }^{a}$ Holdout, PN: Profil No

Diğer taraftan hedef tüketici piyasalarının bölümlendirilmesinde kullanılan içme sütü tüketim sıklıkları (her gün, haftada 3-4 ve 15 günde 3-4 kez tüketim) dikkate alınmıştır. Bu tüketim sıklıklarına dayalı olarak içme sütü tüketen tüketiciler sırasıyla yoğun, 1 lımlı ve düşük düzeyde içme sütü tüketenler olarak üç hedef piyasa segmenti oluşturulmuştur (Kotler ve Armstrong, 2004).

\section{Istatistiksel Analiz}

Conjoint analiz: Conjoint analiz, perakendecilerin farklılaştırılmış ürün modelleri teklifleri karşısında tüketicilerin satın alma kararlarına çok değişkenli istatistik tekniklerini uygulayarak etkili ürün tasarımlarını geliştirmek ve piyasa paylarını tespit etmek için kullanılan bir piyasa araştırma aracıdır. Bu teknik, faktör ve seviyeleri tarafından tanımlanan alternatif ürün profillerinin bireysel ve kitlesel değerlendirilmesinden elde edilen tüketici satın alma modellerinin yapıları hakkında araştırmacılara bilgi sağlar (Green ve Krieger, 1991). Conjoint analizi uygulamak için kullanılan veriler, alternatif ürün profillerinin tüketici değerlendirmelerini kapsamaktadır. $\mathrm{Bu}$ analiz tekniğinde, her bir faktör ve onların seviyelerinin ön piyasa araştırması ile belirlenmesi, fraksiyonel faktöriyel tasarımı ve ölçek tipinin belirlenmesini takip eden veri toplama süreci, dört aşamada gerçekleşir ve bu aşamaları takiben conjoint model tanımlaması yapılır (Uzundumlu ve Topcu, 2016).

Conjoint analizin birinci ve ikinci adımda, uygun faktör ve faktör seviyeleri belirlenerek, tam profil yaklaşımı ile kart dizaynları gerçekleştirilmektedir. Mevcut çalışmadaki 6 faktör ve 17 faktör seviyesi belirlenmiştir (Çizelge 1). Takip eden aşamada, conjoint analiz için tam profil yaklaşımı altında tüketiciler tercih sıralaması yapabilsin diye onlara sunulan farklı kombinasyonların hesaplanmasında kullanılan faktör seviyeleri dikkate alınarak toplam $486\left(3^{5} \times 2\right)$ adet kuramsal senaryo elde edilmiştir. Fakat, elde edilen ürün profil sayısının çok fazla olmasından dolayı tüketicilerin bunları anlamlı bir şekilde sıralaması olanaksızdır. Bu yüzden, Generate Orthogonal Design prosedürü kullanılarak, fraksiyonel faktöriyel tasarım ile içme sütü profil sayısı 20 adet profile indirgenmiştir (Çizelge 2).

Son olarak, her bir faktörün nispi önemi ve faktör seviyelerinin kısmi faydalarını belirlemek için faktörler ile derecelemeleri arasındaki beklenen ilişkileri belirleyen modelin faktör alt komutları vasıtasıyla tanımlanmalıdır. Bunun için en yaygın kullanılan model, niteliklerin ayrı ayrı kısmi faydalarının toplamlarını ifade eden doğrusal modellerdir (SPSS Conjoint 20.0, 2015). Conjoint modellerde ayrık modeller; faktör seviyelerinin kategorik ve faktörler ile siralamalar arasında herhangi bir ön görünün bulunulmadığını, fakat doğrusal modeller; faktörler ile sıraları arasındaki doğrusal ilişkileri pozitif ya da negatif yönlü olarak ifade ederler. Mevcut çalışmada; marka pozitif yönlü (linear more), fiyat negatif yönlü (linear less), üretim ve işleme tekniği, ürün içeriği ve orijin (discrete) olarak modelde tanımlanmıştır.

Ödeme istekliliği (WTP) simülasyonu: Tüketicilerin içme sütü tüketim tercihi ve satın alma kararı üzerinde etkili olan Kuzeydoğu Anadolu, Doğu Karadeniz ve Marmara/Ege Bölgeleri orijinli içme sütü ile her bir orijin için üç farklı fiyat seviyeleri (3, 6 ve 9 TL) kullanılarak ve diğer faktörler sabit tutularak; tüketicilerin her bir bölge orijinli içme sütü için ödeme isteklilikleri (WTP) belirlenmiştir (Çizelge 3). WTP, maksimum toplam fayda temin eden tüketicilerin profillerine değişken olan fiyat seviyeleri ile bölge orijinli her bir simülasyon profillerinin oransal fayda olasılığı olarak belirleyen BTL (BradleyTerry-Luce) modeli ile sadece fiyat seviyelerine bağlı simülasyon profilleri ile tasarlanan profillerin toplam faydalarının oran olasılıklarının doğal logaritmasına dayalı mamulün ödeme istekliliği için ise Logit model kullanılmıştır (SPSS Conjoint 20.0, 2015; Green ve Krieger, 1991). 
Çizelge 3 Bölge orijinli içme sütleri için WTP dikkate alan simülasyon modelleri

Table 3 Simulation patterns considering WTP for drinking milk with the region of origin

\begin{tabular}{c|llllll}
\hline PN $^{*}$ & Üretim tekniği & İşleme tekniği & Orijini (bölgesi) & Marka & Ürün içeriği & Fiyat \\
\hline 21 & Organik & Pastörize süt & Kuzeydoğu Anadolu & Ulusal marka & Tam yağlı süt & 3 TL \\
22 & Organik & Pastörize süt & Kuzeydoğu Anadolu & Ulusal marka & Tam yağlı süt & 6 TL \\
23 & Organik & Pastörize süt & Kuzeydoğu Anadolu & Ulusal marka & Tam yağlı süt & 9 TL \\
24 & Organik & Pastörize süt & Doğu Karadeniz & Ulusal marka & Tam yağlı süt & 3 TL \\
25 & Organik & Pastörize süt & Doğu Karadeniz & Ulusal marka & Tam yağlı süt & 6 TL \\
26 & Organik & Pastörize süt & Doğu Karadeniz & Ulusal marka & Tam yağlı süt & 9 TL \\
27 & Organik & Pastörize sut & Marmara/Ege & Ulusal marka & Tam yağlı süt & $3 \mathrm{TL}$ \\
28 & Organik & Pastörize sut & Marmara/Ege & Ulusal marka & Tam yağlı süt & $6 \mathrm{TL}$ \\
29 & Organik & Pastörize süt & Marmara/Ege & Ulusal marka & Tam yağlı süt & $9 \mathrm{TL}$ \\
\hline
\end{tabular}

PN: Profil No, *Simülasyon

Piyasa payı simülasyonu: Piyasa payının belirlenmesinde, faktör ve faktör seviyelerine göre dizayn edilmiş ürün profillerinden en çok tercih edilen simülasyon örneklerinden seçilen her birinin olasılığına dayalı Maksimum Fayda, BTL (Bradley-Terry-Luce) ve Logit Modeller kullanılmıştır (SPSS Conjoint 20.0, 2015; Murphy ve ark., 2004). Maksimum fayda modeli, katılımcıların toplamlarına atfedilen profilleri basit bir şekilde seçmek için cevap verenlerin sayısına bağlı piyasa payı olasılığını tanımlar ve her bir cevap veren için tahmin edilen birincil seçim, en büyük toplam faydayı sunan profildir. Diğer taraftan BTL model, bütün katılımcılar genelinde ortalama bütün simülasyon profilleri için sağlanan faydaya bir profilin faydasının oranı olarak olasılığ 1 tanımlar. Logit model ise, fonksiyonel olarak BTL modele benzerlik gösterir fakat faydaların yerine faydaların doğal logaritmasını kullanır.

\section{Bulguları ve Tartışma}

\section{Içme Sütü Tüketiminde Nispi ve Kısmi Faydalar}

Tüketicilerin içme sütü tüketim tercihi ve satın alma kararında pazarlama karması bileşenlerinin nitelikleri, niteliklerin nispi önemleri, nitelik seviyelerinin fayda düzeyleri, Çizelge 4'de sunulmuştur. Kitlesel olarak toplam tüketicilerin içme sütü tüketim tercihi ve satın alma kararı üzerinde etkili faktörler; $\% 30 ; \% 16 ; \% 15,3 ; \% 15$; $\% 14$ ve \%11'lik nispi önemleri ile sırasıyla üretim tekniği, fiyat, marka tipi, bölge orijini, işleme tekniği ve süt içeriği olarak belirlenmiştir. İçme sütü tüketen tüketicilere en yüksek kısmi faydaları sağlayan faktör düzeyleri ise organik üretim, pastörize süt, ulusal marka, tam yağlı süt, Doğu Karadeniz orijini ve düşük fiyat seviyelerinden oluşmaktadır (Çizelge 4).

Tüketicilerin süt ve süt ürünleri satın alma kararları üzerinde etkili olan faktörlerle ilgili yapılmış önceki çalışmalar; üretim tekniğinin \%20 ile \%35 (Bellows ve ark., 2010; Tsourgiannis ve ark., 2011; Almli ve ark., 2015; Pinto ve ark., 2016; Topcu, 2019; Topcu ve Sar1, 2019), işleme tekniğinin \%5 ile \%20 (Grubor ve Djokic, 2015; Murhy ve ark., 2015; Topcu, 2019; Topcu ve Sar1, 2019), süt içeriğinin \%7 ile \%20 (Adanacioğlu ve Albayram, 2012; Murhy ve ark., 2015; Gracia, 2016; Pinto ve ark., 2016; Topcu, 2019), marka tipinin \%15 ile \%30 (Sichmann ve ark., 2011; Pelsmaeker ve ark., 2017; Topcu ve Sarı, 2019), fiyatın \%10 ile \%25 (Adanacığlu ve Albayram, 2012; Liang, 2015; Götze ve ark., 2016; Topcu, 2019) ve bölge orijinin \%14 ile \%25 (Adanacıoglu ve
Albayram, 2012; Cacciolatti ve ark., 2015; Aprile ve ark., 2016; Grunert ve Aachmann, 2016; Topcu ve Sar1, 2019) aralıklarında etkili olduğunu rapor etmiştir. Tüketicilerin süt ve süt ürünleri satın alma modellerini etkileyen bu faktörlerin nispi önem aralıkları, mevcut araştırmanın sonuçlarını kapsamakta ve desteklemektedir.

\section{İçme Sütü Tüketimi Iç̧in Ödeme İstekliliği (WTP)}

İçme sütü satın alma kararı üzerinde organik üretim, pastörize organik tam yağlı ulusal markalı süt profillerinde üç fiyat ve bölge orijini düzeylerine göre dizayn edilen simülasyon profilleri dikkate alınarak, tüketicilerin ödeme isteklilikleri, Çizelge 5'de verilmiştir. Maksimum faydanın sağlanmış olduğu 27 numaralı profilde tüketicilerin en düşük (3 TL) perakende fiyatı düzeyinde Marmara orijinli içme sütü için ödeme istekliliği (WTP) \%26 olarak ölçülmüştür. Yine en düşük fiyat düzeyinde Kuzeydoğu Anadolu ve Doğu Karadeniz Bölgeleri içme sütü için WTP sırasıyla \%16 ve \%12 olarak belirlenmiştir.

İçme sütünün en düşük fiyat düzeyin \%100 artışı ile 6 TL olması durumunda tüketicilerin WTP; Marmara, Kuzeydoğu Anadolu ve Doğu Karadeniz Bölgeleri orijinleri için sırasıyla $\% 15, \% 9$ ve $\% 6,3$ olarak hesaplanmıştır. Benzer şekilde içme sütünün en düşük fiyat düzeyinin \%200 artış ile 9 TL olması durumunda ise WTP; Marmara, Kuzeydoğu Anadolu ve Doğu Karadeniz Bölgeleri orijinleri için sırasıyla \%8,3; \%5,2 ve \%3,5 olarak belirlenmiştir. Sonuç olarak, bölge orijinli içme sütü profillerinin simülasyonunda, satın alma kararında toplam faydanın maksimum kılındığı Marmara/Ege bölge orijini için tüketicilerin WTP, bütün fiyat seviyelerinde daha yüksek düzeylerdedir.

Araştırma sonuçları, içme sütünün bölge orijinleri ile üç farklı fiyat seviyeleri arasındaki ters bir ilişkiyi ortaya koyarak, daha fazla tercih edilen bölge orijinlerinin WTP daha yüksek olduğunu göstermiştir. Mevcut sonuçlara benzerlik arz eden çeşitli süt ürünleri karması nitelikleri ile onlara takdir edilen fiyatlar arasındaki ilişkiler, çeşitli araştırmalarda ortaya konulmuştur. Sichmann ve ark. (2010), tüketicilerin sütlü çikolata markaları ile belirlenen temel fiyatin (1\$) \%100 ve \%200 artirılması ile hedef kitlenin \%60'nın 2\$ ve \%25'inin 3\$ ödemeye hazır olduklarını rapor etmişlerdir. Başka bir araştırmada hayvan dostu etiketler ile işaretlenmiş içme sütleri için litre fiyatının $\% 5, \% 10, \% 20, \% 50$ ve $\% 100$ artırılarak WTP, sirasıly $\% 24, \% 23, \% 16, \% 8$ ve $\% 4$ olduğu belirlenmiştir (Graaf ve ark., 2016). 
Çizelge 4 İçme sütü için faktörlerinin nispi önemi ve faktör seviyelerinin kısmi faydaları

Table 4 Relative importance of the attributes and partly utilities of their levels for drinking milk

\begin{tabular}{|c|c|c|c|c|c|c|c|c|}
\hline \multirow{4}{*}{$\begin{array}{c}\text { Mamul nitelik ve } \\
\text { seviyeleri }\end{array}$} & \multicolumn{8}{|c|}{ İçme sütü tüketim sıklıkları } \\
\hline & \multicolumn{2}{|c|}{$\begin{array}{l}\text { Yoğun düzeyde } \\
\text { tüketenler }\end{array}$} & \multicolumn{2}{|c|}{$\begin{array}{l}\text { Ilımlı düzeyde } \\
\text { tüketenler }\end{array}$} & \multicolumn{2}{|c|}{$\begin{array}{c}\text { Düşük düzeyde } \\
\text { tüketenler }\end{array}$} & \multicolumn{2}{|c|}{ Toplam tüketiciler } \\
\hline & $\mathrm{F}$ & S.E. & $\mathrm{F}$ & S.E. & $\mathrm{F}$ & S.E. & $\mathrm{F}$ & S.E. \\
\hline & \multicolumn{8}{|c|}{ Üretim tekniği } \\
\hline \multirow{4}{*}{$\begin{array}{l}\text { Organik } \\
\text { Geleneksel } \\
\qquad \text { Nispi önemi }\end{array}$} & 1,161 & 0,117 & 1,167 & 0,065 & 1,057 & 0,190 & 1,140 & 0,080 \\
\hline & $-1,161$ & 0,117 & $-1,167$ & 0,065 & $-1,057$ & 0,190 & $-1,140$ & 0,080 \\
\hline & \multicolumn{2}{|c|}{$\% 31,20$} & \multicolumn{2}{|c|}{$\% 31,25$} & \multicolumn{2}{|c|}{$\% 24,55$} & \multicolumn{2}{|c|}{$\% 29,69$} \\
\hline & \multicolumn{8}{|c|}{ İşleme tekniği } \\
\hline \multirow{5}{*}{$\begin{array}{l}\text { Ham süt } \\
\text { UHT süt } \\
\text { Pastörize süt } \\
\quad \text { Nispi önemi } \\
\end{array}$} & 0,108 & 0,236 & $-0,600$ & 0,087 & 0,252 & 0,254 & $-0,191$ & 0,107 \\
\hline & $-0,382$ & 0,236 & $-0,042$ & 0,087 & $-0,739$ & 0,254 & $-0,305$ & 0,107 \\
\hline & 0,274 & 0,236 & 0,642 & 0,087 & 0,486 & 0,254 & 0,496 & 0,107 \\
\hline & \multicolumn{2}{|c|}{$\% 8,82$} & \multicolumn{2}{|c|}{$\% 16,64$} & \multicolumn{2}{|c|}{$\% 14,22$} & \multicolumn{2}{|c|}{$\% 13,73$} \\
\hline & \multicolumn{8}{|c|}{ Marka tipi } \\
\hline \multirow{5}{*}{$\begin{array}{l}\text { Ulusal marka } \\
\text { Ozel marka } \\
\text { Jenerik marka } \\
\qquad \text { Nispi önemi }\end{array}$} & $-0,342$ & 0,205 & $-0,509$ & 0,075 & $-1,144$ & 0,220 & $-0,606$ & 0,093 \\
\hline & $-0,684$ & 0,409 & $-1,108$ & 0,150 & $-2,288$ & 0,440 & $-1,211$ & 0,186 \\
\hline & $-1,026$ & 0,614 & $-1,527$ & 0,226 & $-3,432$ & 0,659 & $-1,817$ & 0,279 \\
\hline & \multicolumn{2}{|c|}{$\% 9,18$} & \multicolumn{2}{|c|}{$\% 13,63$} & \multicolumn{2}{|c|}{$\% 26,56$} & \multicolumn{2}{|c|}{$\% 15,29$} \\
\hline & \multicolumn{8}{|c|}{ Süt içeriği } \\
\hline Light süt & $-0,799$ & 0,236 & $-0,178$ & 0,087 & $-0,302$ & 0,254 & $-0,393$ & 0,107 \\
\hline Yarım yağlı süt & 0,302 & 0,236 & $-0,178$ & 0,087 & $-0,126$ & 0,254 & $-0,022$ & 0,107 \\
\hline \multirow{3}{*}{$\begin{array}{l}\text { Tam yağli süt } \\
\text { Nispi önemi }\end{array}$} & 0,497 & 0,236 & 0,356 & 0,087 & 0,428 & 0,254 & 0,415 & 0,107 \\
\hline & & & & & & & & \\
\hline & & & & Bölg & rijini & & & \\
\hline Kuzeydoğu Anad. & $-0,285$ & 0,236 & $-0,480$ & 0,087 & $-0,667$ & 0,254 & $-0,465$ & 0,107 \\
\hline Doğu Karadeniz & 0,687 & 0,236 & 0,576 & 0,087 & 0,797 & 0,254 & 0,660 & 0,107 \\
\hline Marmara/Ege & $-0,403$ & 0,236 & $-0,096$ & 0,087 & $-0,131$ & 0,254 & $-0,196$ & 0,107 \\
\hline Nispi önemi & & & & & & & & \\
\hline & & & & Fiya & $\mathrm{g} / \mathrm{Lt})$ & & & \\
\hline Düşük fiyat (3 TL) & $-0,698$ & 0,205 & $-0,642$ & 0,075 & $-0,396$ & 0,220 & $-0,602$ & 0,093 \\
\hline Orta fiyat (6 TL) & $-1,396$ & 0,409 & $-1,284$ & 0,150 & $-0,793$ & 0,440 & $-1,204$ & 0,186 \\
\hline Yük. fiyat (9 TL) & $-2,094$ & 0,614 & $-1,927$ & 0,226 & $-1,198$ & 0,659 & $-1,806$ & 0,279 \\
\hline Nispi önemi & & & & & & & & \\
\hline Sabit değer & 11,193 & 0,605 & 11,413 & 0,222 & 12,229 & 0,650 & 11,536 & 0,275 \\
\hline & & & zlenen v & klenen & şkenler a & ndaki il & & \\
\hline İstatistik ölçümler & Değer & $\mathrm{P}$ & Değer & $\mathrm{P}$ & Değer & $\mathrm{P}$ & Değer & $\mathrm{P}$ \\
\hline Pearsons's R & $0,954^{* * *}$ & 0,000 & $0,993^{\text {**** }}$ & 0,000 & $0,956^{* * *}$ & 0,000 & $0,989^{* * *}$ & 0,000 \\
\hline Kendall's tau & $0,804^{* * * *}$ & 0,000 & $0,935^{\text {*** }}$ & 0,000 & $0,866^{* * *}$ & 0,000 & $0,895^{* * *}$ & 0,000 \\
\hline
\end{tabular}

F: Faydalar, S.E.: Standart hata, P: Önem seviyesi ${ }^{* * *} \mathrm{P}<0,001$

Çizelge 5 Bölge orijinli içme sütü için tüketicilerin WTP

Table 5 Consumers' WTP for drinking milk with the region of origin

\begin{tabular}{c|ccccr}
\hline \multirow{2}{*}{ Bölge Orijini } & \multirow{2}{*}{ Fiyat (TL) } & \multirow{2}{*}{ Kart No } & \multicolumn{3}{c}{ WTP } \\
\cline { 4 - 6 } & & & Maksimum fayda (\%) & Bradley-Terry-Luce (\%) & Logit (\%) \\
\hline \multirow{3}{*}{ Kuzeydoğu Anadolu } & 3 & 21 & 0,00 & 11,60 & 15,80 \\
& 6 & 22 & 0,00 & 11,00 & 9,00 \\
& 9 & 23 & 0,00 & 11,40 & 5,20 \\
\hline \multirow{3}{*}{ DoğuKaradeniz } & 3 & 24 & 0,00 & 10,70 & 1,60 \\
& 6 & 25 & 0,00 & 12,10 & 6,30 \\
& 9 & 26 & 0,00 & 11,60 & 3,50 \\
\hline \multirow{3}{*}{ Marmara/Ege } & $3^{*}$ & 27 & 100,00 & 11,00 & 14,50 \\
& 6 & 28 & 0,00 & 0,00 & 8,30 \\
\hline
\end{tabular}

Toplam faydanın maksimum olduğu profil (\%100)

Diğer taraftan, Yan ve Ames (2014) tarafindan yürütülen çalışmanın sonuçları; fiyatı $1 \mathrm{RMB}$ olan çocuk peynirinin yüksek kalite ve sertifika tescilleri altında farklılaştırılması ile fiyatının $\% 100$ ve $\% 400$ artırılmasıyla elde edilen 2 ve 4 RMB seviyelerinden satın alan tüketicilerin oranlarının sırasıyla $\% 35, \% 10$ ve $\% 2$ olduğunu ortaya koymuştur. Danimarka'da yapılan bir araştırmada da tüketicilerin \%51, \%29 ve
$\% 13$ 'ünün bölge orijinli peynirler için sırasıyla $\% 5, \% 10$ ve \%20 daha fazla ödemeye istekli oldukları rapor edilmiştir (Cernae, 2011). Benzer şekilde TRA1 Bölgesi'nde, 3 TL'lik temel fiyat seviyesi ile bu fiyatın \%100 (6 TL) ve \%200 (9 TL) artırılması ile elde edilen fiyat düzeylerinden Doğu Karadeniz bölge orijinli içme sütleri için tüketicilerin WTP $\% 30, \% 16$ ve $\% 9$ olarak hesaplanmıştır (Topcu ve Sarı, 2019). 


\section{İçme Sütü Profil Tercihlerinin Piyasa Payları}

Tüketicilerin içme sütü satın alma kararında etkili olan faktör ve faktör seviyelerine göre tasarlanan 20 içme sütü profilinin piyasa payları, Çizelge 6'da verilmiştir. Tüketicilerin \%100 toplam fayda temin ettiği 7 numaralı içme sütü profilinin piyasa payı, \%34 ile en yüksek düzeydedir. Bu profilin belirgin özelliği, Doğu Karadeniz orijinli organik üretim ve pastörizasyon işlemi ile muamele edilmiş düşük fiyatlı özel marka imajı altında tam yağlı içme sütlerinden oluşmasıdır.

Profil 7'yi takip eden 6 ve 1 numaralı içme sütü profillerinin piyasa payları $\% 12$ ve $\% 10$ olarak hesaplanmıştır. Bu profilleri 7 numaralı profillerden ayıran en önemli farklar; Marmara/Ege orijini, UHT süt işleme tekniği ve ulusal marka faktör düzeyleridir. Orthogonal olarak türetilen içme sütü profillerinden en yüksek tüketici tatmini ve piyasa payı sağlayan Doğu Karadeniz ve Marmara bölge orijinli, organik üretim, pastörize ve UHT tam yağlı sütlerin özel ya da ulusal marka imajları altında farklılaştırılması, hem tüketim memnuniyeti hem de piyasa payının artırılmasına önemli katkılar sağlayabilir.

Çizelge 6 Bölge orijinli içme sütü profilleri için piyasa payları

Table 6 Market shares for drinking milk profiles with the region of origin

\begin{tabular}{|c|c|c|c|}
\hline \multirow{2}{*}{$\begin{array}{c}\text { Kart } \\
\text { Profil No }\end{array}$} & \multicolumn{3}{|c|}{ Piyasa payları } \\
\hline & $\begin{array}{c}\text { Maksimum } \\
\text { fayda }(\%)\end{array}$ & $\begin{array}{c}\text { Bradley-Terry- } \\
\text { Luce }(\%)\end{array}$ & $\begin{array}{c}\text { Logit } \\
(\%)\end{array}$ \\
\hline 1 & 0,00 & 5,90 & 10,10 \\
\hline 2 & 0,00 & 5,00 & 1,90 \\
\hline 3 & 0,00 & 3,40 & 0,10 \\
\hline 4 & 0,00 & 5,30 & 4,60 \\
\hline 5 & 0,00 & 4,80 & 1,70 \\
\hline 6 & 0,00 & 6,00 & 11,70 \\
\hline $7^{*}$ & 100,00 & 6,50 & 33,70 \\
\hline 8 & 0,00 & 4,30 & 0,60 \\
\hline 9 & 0,00 & 4,20 & 0,50 \\
\hline 10 & 0,00 & 4,00 & 0,30 \\
\hline 11 & 0,00 & 5,10 & 2,40 \\
\hline 12 & 0,00 & 5,50 & 5,00 \\
\hline 13 & 0,00 & 4,40 & 0,70 \\
\hline 14 & 0,00 & 5,80 & 9,70 \\
\hline 15 & 0,00 & 4,40 & 0,70 \\
\hline 16 & 0,00 & 5,50 & 5,20 \\
\hline 17 & 0,00 & 4,60 & 1,00 \\
\hline 18 & 0,00 & 5,00 & 2,10 \\
\hline 19 & 0,00 & 4,40 & 0,70 \\
\hline 20 & 0,00 & 5,70 & 7,40 \\
\hline
\end{tabular}

"Maksimum faydanın sağlandığı profil (\%100)

Mevcut araştırmanın sonuçları, orthogonal olarak tasarlanmış 20 içme sütü profillerinin araştırma bölgesindeki piyasa paylarının \%34 ile \%0,1 aralığında değiştiğini ve bölgede yüksek toplam fayda sunan Doğu Karadeniz orijinli içme sütlerinin en yüksek piyasa payına ulaştığını göstermiştir. Benzer şekilde, Topcu (2019) tarafindan TRA1 bölgesinde yürütülen bir araştırmada tüketicilerin 1sıl işlem görmemiş organik süt tüketim tercih profillerinin piyasa payının $\% 33$ ile $\% 2$ arasında değiştiğini ve Kuzeydoğu Anadolu ile Doğu Karadeniz bölge orijinlerinin en yüksek piyasa paylarına sahip olduklarını ortaya koymuştur. Ayrıca İrlanda'da peynir tüketim tercih profilleri ile ilgili yapılan çalışmada, iki farklı tüketici grupları için 11 peynir profili tasarlanmış ve onların piyasa paylarının da \% 18 ile $\% 4$ aralığında teşekkül ettiği rapor edilmiştir (Murphy ve ark., 2004). Dolayısıyla mevcut çalışmanın piyasa paylarının ölçüm sonuçları, daha önceden yapılmış araştırma sonuçları tarafindan da desteklenmiştir.

Sonuç olarak; üç farklı bölge orijini ve fiyat seviyeleri ile dizayn edilen WTP simülasyon profillerinde toplam faydanın maksimum kılındığı Marmara/Ege bölge orijinli içme sütleri, üç farklı fiyat seviyelerinde tüketicilerin en yüksek ödeme istekliliği sergilemelerine olanak sağlamıştır. Bu bölge orijinini takip eden ikinci ödeme istekliliği en yüksek bölge orijini ise Kuzeydoğu Anadolu bölge orijinidir. Tüketicilerin tatmin düzeylerini maksimum düzeylere çıkaran ve yüksek ödeme istekliliklerini temin eden Marmara/Ege ve Kuzeydoğu Anadolu bölge orijinli ulusal markalı içme sütü profillerinin perakende düzeyinde mamul hattı ve derinliklerinin artırılması, içme sütü yayılımının ve erişilebilirliğinin temini yönünden büyük önem arz etmektedir.

Diğer taraftan orthogonal dizaynlarla elde edilen içme sütü profillerinden 7 numaralı ürün profili (Doğu Karadeniz orijinli organik üretim ve pastörizasyon işlemi ile muamele edilmiş düşük fiyatlı özel marka imajı altında tam yağlı süt), tüketicilerin toplam faydasını maksimum kılarak, \%34'lük en yüksek piyasa payını teşekkül ettirmiştir. Perakende satış noktalarında bu niteliklere sahip içme sütlerinin konumlandırması hem arz edenlerin daha rantabl çalışarak yüksek kar marjları elde etmelerine hem de tüketicilerin daha yüksek tatmin sağlayarak istedikleri içme sütlerine ulaşmalarına olanak sağlayabilir.

\section{Kaynaklar}

Adanacioğlu H, Albayram Z. 2012. A conjoint analysis of consumer preferences for traditional cheeses in Turkey: A case study on Tulum Cheese. Korean J. Food Sci. An., 32 (4): 458-466.

Anonim 2014. Coğrafi işaretlerde dünyanın neresindeyiz. Erişim Adresi: http://apelasyon.com [Erişim: 15.03.2018]

Anonim 2015. Coğrafi işaretli ürünler için stratejiler. Erişim Adresi: http://www.gidahatti.com [Erişim: 15.03.2018]

Allen S, Goddard E. 2012. Consumer preferences for milk and yogurt attributes: How health beliefs and attitudes affect choices. Agricultural and Applied Economics Association's 2012 Annual Meeting, August 12-14, Seattle, Washington.

Almli VL, Ovrum A, Hersleth M, Almoy T, Naes T. 2015. Investigating individual preferences in rating and ranking conjoint experiments: A case study on semi-hard cheese. Food Qual. \& Pref., 39: 28-39.

Aprile MC, Caputo V, Nayga RM. 2016. Consumers' preferences and attitudes toward local food products. J. Food Prod. Marketing, 22 (1): 19-42.

Aprile MC, Gallina G. 2008. Quality perception using signals on food label: An analysis on Italian consumers. $18^{\text {th }}$ Annual IAMA Symposium, June 17, 2008, Monterey, USA.

ASUD 2019. Süt ve süt ürünleri tüketimi. Erişim Adresi: http://www.asuder.org.tr. [Erişim: 04.02.2019].

Azadbakht L, Mirmiran P, Esmaillzadeh A, Azizi F. 2005. Fairy consumption is inversely associated with the prevalence of the metabolic syndrome in Tehranian adults. Am. J. Clin. Nutr., 82 (3): 523-30.

Bellows AC, Alcavaz G, Hallman WK. 2010. Gender and food, a study of attitudes in the USA towards organic, local, U.S. grown and GM-free foods. Appetite 55: 540-550.

Black RE, Williams SM, Jones IE, Goulding A. 2002. Children who avoid drinking cow milk have low dietary calcium intakes and poor bone health. Am. J. Clin. Nutr., 76: 675-80. 
Bonany J, Buehler A, Carbo J, Codarin S, Donati F. 2013. Consumer eating quality acceptance of new apple varieties in different European countries. Food Quality and Preference, 30 (2013): 250-259.

Cacciolatti LA, Garcia CC, Kalantzakis M. 2015. Traditional food products: the effect of consumers' characteristics, product knowledge, and perceived value on actual purchase. J. Inter. Food and Agribus. Marketing, 27: 155-176.

Cernea C. 2011. Protected geographical origins. A study of Danish consumers' willingness to pay for domestic protected geographical indication cheese products, (MS Thesis). Aarhus University, Aarhus, Denmark.

Chamorro A, Rubio S, Miranda FJ. 2014. The region of origin (ROO) effect on purchasing preferences: The case of a multiregional designation of origin. British Food Journal, 117 (2): 820-839.

Denver S, Jensen JD. 2014. Consumer preferences for organically and locally produced apples. Food Quality and Preference, 31 (2014): 129-134.

FAOSTAT 2019. Download and visualize data of livestock processed and primary product production. Erişim Adresi: http://www.fao.org/faostat. [Erişim: 04.02.2019].

Fotopoulos C, Krystallis A. 2011. Are quality labels a real market advantage? A conjoint application on PDO olive oil. Journal of International Food and Agribusiness, 12: 1-22.

Götze F, Mann S, Ferjani A, Kohler A, Heckelei T. 2016. Explaining market shares of organic food: evidence from Swiss household data. British Food J., 118 (4): 931-945.

Graaf S, Vanhonacker F, Loo EJV, Bijttebier J, Lauwers L, Tuyttens FAM, Verbeke W. 2016. Market opportunities for animal-friendly milk in different consumer segments. Sustainability 1302 (8): 1-17.

Gracia TMA. 2016. Consumers' willingness to pay for light, organic and PDO cheese. British Food J., 118 (3): 560-571.

Green PE, Krieger AM. 1991. Segmenting markets with conjoint analysis. Journal of Marketing, 55 (4): 20-31.

Groot E, Albusi LM. 2015. A bottom-up model to describe consumers' preferences towards late season peaches. Spanish Journal of Agricultural Research, 13 (4): 1-13.

Grubor A, Djokic N. 2016. Organic food consumer profile in the Republic of Serbia. British Food J., 118 (1): 164-182.

Grunert KG, Aachmann K. 2016. Consumer reactions to the use of EU quality labels on food products. Food Control, 59 (1): 178-187.

Hassan D, Monier-Dilhan S, Orozco V. 2011. Measuring consumers' attachment to geographical indication. Journal of Agricultural and Food Industrial Organisation, 9 (1): 35-50.

Huth PJ, di-Renzo DB, Miller GD, 2006. Major scientific advances with dairy foods in nutrition and health. Journal of Dairy Science, 89: 1207-1221.

Kan M, Gülçubuk B, Küçükçongar M. 2012. Coğrafi işaretlerin kırsal turizmde kullanılma olanakları. KMÜ Sosyal ve Ekon. Arş. Derg., 6(2): 52-64.

Li EX, Drake MA. 2015. Sensory perception, nutritional role, and challenges of flavored milk for children and adults. J. Food Sci., 80 (4): 665-670.

Liang R. 2015. Predicting intentions to purchase organic food: the moderating effects of organic food prices. British Food J., 118 (1): 183-199.

Lim K, Hu W, Maynard LJ, Goddard E. 2014. A taste for safer beef? How much does consumers' perceived risk influence willingness to pay for country-of-origin labeled beef. Agribusiness, 30 (1): 17-30.

Miller GD. 2000. Benefits of dairy product consumption on blood pressure in humans: A summary of the biomedical literature. J. Amer. Coll. Nut., 19 (2): 147-164.

Mobley AR, Jakob DJ, Maulding M. 2014. Attitudes, beliefs, and barriers related to milk consumption in older, low-income women. J. Nut. Educ. Behav., 46 (6): 554-559.
Munoz CX, Johnson EC, McKenzie AL, Guelinck I., Graverholt G, Casa DJ, Armstrong LE. 2014. Habitual total water intake and dimensions of mood in healthy young women. Appetite, 92 (1): 81-86.

Murphy MM, Douglass JS, Johnson RK, Spence LA. 2004. A conjoint analysis of Irish consumer preferences for farmhouse cheese. British Food Journal, 106 (4): 288-300.

Murphy MM, Cowan C, Meehan H, O'Reilly S. 2008. Drinking flavored or plain milk is positively associated with nutrient intake and is not associated with adverse effects on weight status in US children and adolescents. J. Amer. Diet. Ass., 108: 631-639.

Murphy M, Cowan C, Meehan H, 2015. A conjoint analysis of Irish consumer preferences for farmhouse cheese. British Food J., 106 (4): 288-300.

Pelsmaeker S, Schouteten J, Lagast S, Dewettinck K, Gellynck X. 2017. Is taste the key driver for consumer preference? A conjoint analysis study. Food Qual. \& Pref. 62: 323-331.

Pinto VRA, Melo LF, Balbino DF, Novaes JF, Negrete MC, Sousa TD. 2016. The evaluation of consumer behavior influence on the buying process of dairy products in Minas Gervais State, Brazil. J. Food and Nut. Res., 4(1): 51-59.

Sichtmann C, Wilken R, Diamantopoulos A. 2011. Estimating willingness-to-pay with conjoint analysis: Can consumer characteristics explain variations in accuracy? British $\mathrm{J}$. Manage., 22: 628-645.

SPSS Conjoint 20.0 2015. SPSS Base 15 User's Guide, pp. 161184. Chicago, IL.

Şeker İ, Şeker P, Şahin M, Özen VS, Akdeniz A, Erkmen O, Kışlalıoğlu İ, Sargın G, Doğu GB. 2012. Elazığ İli merkez ilçede tüketicilerin süt tüketim alışkanlıkları ve bu alışkanlıkları etkileyen faktörlerin belirlenmesi. Sağlık Bilimleri Veteriner Dergisi, 26(3): 131-143.

Tsakiridou E, Mattas K, Mpletsa Z. 2009. Consumers' food choices for specific quality food products. Journal of Food Products Marketing, 15: 200-212.

Tekelioğlu Y. 2016. Yöresel ürünler, coğrafi işaretler ve Türkiye uygulamalar1. Gastro Dergisi, 59: 118-122.

Topcu Y. 2019. Tüketicilerin bölge orijinli organik içme sütü tercih profilleri ve piyasa payları: TRA1 Bölgesi örneği. MAS International Conference, 849-859, May 2-5, 2019, Erzurum.

Topcu Y, Sarı MM. 2019. Bölge orijinli konvansiyonel içme sütü tüketim memnuniyeti ve ödeme istekliliği: TRA1 Bölgesi örneği. ICAFOP 3. International Conference, 1298-1310, April 16-18, 2019, Trabzon.

Topcu Y. 2015. Turkish consumer decisions affecting ice cream consumption. Italian Journal of Food Science, 27 (1): 1-11.

TPE 2018. Coğrafi işaretli ürünler. Türk Patent Enstitüsü. Erişim Adresi: http://www.pte.com.tr. [Erişim: 15.03.2018]

Tsourgiannis T, Karasavvoglou A, Florou G. 2011. Consumers' attitudes towards GM free products in European Region. The case of the prefecture of Drama-Kavala-Xanthi in Greece. Appetite 57: 448-458.

Uzundumlu AS, Topcu Y. 2016. Determining Turkish consumers' consumption satisfaction with Erzurum Civil cheese. British Food Journal, 118 (4): 896-914.

Vaskozen T. 2003. Dietary minerals and modification of cardiovascular risk factors. J. Nut. Biochem., 14: 492-506.

Vecciho R, Annunziata A. 2011. The roll of PDO/PGI labelling in Italian consumers' food choices. Agricultural Economic Review, 12 (2): 80-98.

WDS 2017. World Dairy Summit: per capita drinking milk consumption and population. Erişim Adresi: http://www.idfwds2017.com. [Erişim: 15.09.2017].

Yan Y, Ames CW. 2014. Willingness to pay for safer dairy products in China: Evidence from Shanghai customers' purchasing decision of bright dairy's baby cheese, (MS Thesis). Nanjing Agricultural University, Athens, Georgia. 